\title{
Model-Based Re-Design of some Genetic Regulato- ry Circuits to get Genetic Modified Micro-organisms (GMO) by using Engineering Computational Tools
}

\author{
Gheorghe Maria ${ }^{1 *}$, Cristiana Luminita Gijiu ${ }^{1}$, Mara Crisan ${ }^{1}$, Cristina Maria ${ }^{2}$ and Carmen Tociu $^{2}$ \\ ${ }^{1}$ Department of Chemical and Biochemical Engineering, University Politehnica of Bucharest, Romania \\ ${ }^{2}$ National Institute for Research and Development in Environmental Protection, Romania
}

Submission: January 22, 2019; Published: February 20, 2019

*Corresponding author: Gheorghe Maria, Department of Chemical and Biochemical Engineering, University Politehnica of Bucharest, Polizu Str. 1-7, 011061, Bucharest, Romania

\begin{abstract}
The paper is aiming at reviewing the main math modelling and computational tools developed by Maria $(2017,2018)[1-3]$ to in-silico redesign genetic regulation circuits (GRC) in living cells to get GMOs of desired characteristics. A number of suggestive examples (case studies) are mentioned as well.

Keywords: Systems biology; Cell metabolism; Deterministic modelling; Gene expression modelling; Genetic regulatory circuits (GRC); Pareto design of E.coli to get maximum succinate; Design cloned E.coli to get maximum mercury uptake; Design E.coli with a genetic switch biosensor; Design E.coli with a desired glycolytic oscillator; Tryptophan synthesis; Glycolytic oscillator

Abbrevations: GERM: Gene Expression Regulatory Module; CCM: Central Carbon Metabolism; GRC: Genetic Regulation Circuits; GMOs: Genetically Modified Micro-Organisms; VVWC: Variable-Volume-Whole-Cell; SUCC: Succinate; MINLP: Mixed-Integer Nonlinear Programming
\end{abstract}

\section{Short Considerations}

The work is a systematized and reasonable short review of the main published contributions of Dr. Maria in the field of metabolic processes simulation related to the central carbon metabolism (CCM) and modelling the dynamics of the gene expression regulation (GERM) and of the genetic regulation circuits (GRC) in living cells. Application of biochemical engineering, and of nonlinear system control principles and concepts to the modeling of complex cellular processes on deterministic bases are briefly presented with including a rich list of references. These models are essential for understanding and simulating the CCM, useful to in-silico (that is model-based) re-design of genetically modified micro-organisms (GMOs) with applications in industrial biosynthesis, medicine, environmental engineering, vaccine production, biosensors, etc.

A special attention is paid to authors' contributions related to dynamics simulation of the gene expression regulatory modules (GERM) and of genetic regulation circuits (GRC) in living cells, by promoting novel concepts of a novel cell modelling framework, that is the so-called "variable-volumewhole-cell" (VVWC) models. The relatively novel concept of" whole-cell" simulation of cell metabolic processes has been reviewed to prove its advantages when building-up dynamic models of modular structures that can reproduce complex metabolic syntheses inside living cells. The advantages of the more realistic VVWC approach are briefly underlined and exemplified when developing kinetic representations of the gene expression regulatory modules (GERM) that control the protein synthesis and homeostasis of metabolic processes. After a brief presentation of the general concepts and particularities of the VVWC modelling, both past and current experience with constructing effective GERM models is reviewed, together with some rules used when linking GERM-s to build-up models for optimized globally efficient genetic regulatory circuits (GRC), by using quantified regulatory indices evaluated vs. simulated dynamic and stationary environmental perturbations.

The topics belongs to the emergent field of Systems Biology, defined as "the science of discovering, modelling, understanding and ultimately engineering at the molecular level the dynamic relationships between the biological molecules that define living organisms" (Leroy Hood, Inst. Systems Biology, Seattle). Systems Biology is one of the modern tools, which uses advanced mathematical simulation models for in-silico re-design of GMOs that possess specific and desired functions and characteristics. The present work makes a short review of the (bio)chemical engineering principles and deterministic modelling rules used by the Systems Biology for modelling cellular metabolic 
processes [1-2]. This involves application of the classical (bio) chemical engineering modelling techniques (mass balance, thermodynamic principles), algorithmic rules, nonlinear system control theory, and bioinformatics rules. The metabolic pathway representation with continuous and/or stochastic variables remains the most adequate and preferred representation of the cell processes, the adaptable-size and structure of the lumped model depending on available information and the utilisation scope.

\section{Examples}

Exemplifications of using such modular GRC models for insilico design of GMO of industrial use include improving several bioprocesses of industrial interest, that is six case studies of high complexity, extensively described by $[3,10]$ :

i. In-silico design of a genetic switch in E. coli with the role of a biosensor [4];

ii. In-silico design of a cloned E. coli with a maximized capacity of mercury uptake from wastewaters [5];

iii. In-silico design of a genetic modified E. coli with a maximized capacity of succinate (SUCC) production [6];

iv. In-silico design of a genetic modified E. coli with a modified glycolytic oscillator [7];

v. In-silico modulate the bioreactor operating conditions with a modified $E$. coli to maximize the production of tryptophan $[8,9]$.

vi. In-silico re-configure the metabolic pathway for Phenylalanine synthesis in E. coli [10] to maximize its production.

That implies to modify the structure and activity of the involved enzymes, and modification of the existing regulatory loops. Searching variables of the formulated mixed-integer nonlinear programming (MINLP) optimization problem are the followings: the regulatory loops (that is integer variables, taking " 0 " value when the loop has to be deleted, or the value " 1 " when it has to be retained); the enzyme expression levels (that is continuous variables), and all these in the presence of the stoichiometric and thermodynamic constraints. To solve this complex optimization problem, two contrary objectives are formulated: maximization of the Phenyl-alanine selectivity, with minimization of cell metabolites' concentration deviations from their homeostatic levels (to avoid an unbalanced cell growth). The elegant solution of the problem is the so-called Paretooptimal front, which is the locus of the best trade-off between the two adverse objectives. By choosing two problem solution alternatives from this Pareto-curve $[3,10]$, it is to observe the large differences between the two pathways into the cell, fully achievable by genetic engineering.(Anex)

\section{References}

1. Maria G (2017) A review of some novel concepts applied to modular modelling of genetic regulatory circuits. Juniper publishing house, USA.

2. Maria G (2017) Deterministic modelling approach of metabolic processes in living cells - a still powerful tool for representing the metabolic process dynamics. Juniper publishing house, USA.

3. Maria G (2018) In-silico design of Genetic Modified Micro-organisms (GMO) of industrial use, by using Systems Biology and (Bio)Chemical Engineering tools. Juniper publ Inc, USA.

4. Maria G (2014) Extended repression mechanisms in modelling bistable genetic switches of adjustable characteristics within a variable cell volume modelling framework. Chemical \& Biochemical Engineering Quarterly 28(1): 35-51.

5. Maria G, Luta I (2013) Structured cell simulator coupled with a fluidized bed bioreactor model to predict the adaptive mercury uptake by $E$. coli cells. Computers \& Chemical Engineering 58: 98-115.

6. Maria G, Xu Z, Sun J (2011) Multi-objectiveMINLP optimization used to identify theoretical gene knockout strategies for E. coli cell, Chemical \& Biochemical Engineering Quarterly 25(4): 403-424.

7. Maria G (2014) In silico derivation of a reduced kinetic model for stationary or oscillating glycolysis in Escherichia coli bacterium, Chemical \& Biochemical Engineering Quarterly 28(4): 509-529.

8. Maria G, Gijiu CL, Maria C, Tociu C (2018) Interference of the oscillating glycolysis with the oscillating tryptophan synthesis in the $E$. coli cells. Computers \& Chemical Engineering 108: 395-407.

9. Maria G, Mihalachi M, Gijiu CL (2018) In silico optimization of a bioreactor with an E. coli culture for tryptophan production by using a structured model coupling the oscillating glycolysis and tryptophan synthesis. Chemical Engineering Research and Design 135: 207-221.

10. Hatzimanikatis V, Floudas CA, Bailey JE (1996) Analysis and design of metabolic reaction networks via mixed-integer linear optimization, AIChE Jl 42(5): 1277-1292.

11. Maria G, Luta I (2015) Kinetic models for the in-silico design of functionakized mesoporous supports for the controlled release of biological active principles, Printech publ., Bucharest, Romania.

12. Luta I, Maria G (2012) In-silico modulation of the irinotecan release from a functionalized MCM-41 support, Chemical \& Biochemical Engineering Quarterly, 26(4), 309-320 (2012).

13. Maria G (2012) Enzymatic reactor selection and derivation of the optimal operation policy by using a model-based modular simulation platform. Computers \& Chemical Engineering 36(1): 325-341.

14. Maria G (2007) Chemical Process Quantitative Risk Analysis and Modelling of Accident Consequences. Printech, Publ, Bucharest, Romania.

15. Iordache O, Maria G, Corbu S (1991) Statistical Modelling and Estimation of Chemical Process Models. Rom Academy Publ House, Romania.

16. Maria G (2008) Statistical data analysis and correlations. Distributions and estimators. Printech, Romania.

17. Maria G (2018) From residual biomass and inferior quality coal to the synthesis of methanol and then to hydrocarbons and gasoline - a Romanian project of high success. Juniper publ Inc, USA. 
This work is licensed under Creative Commons Attribution 4.0 License DOI: 10.19080/CTBEB.2019.18.555988
Your next submission with Juniper Publishers will reach you the below assets

- Quality Editorial service

- Swift Peer Review

- Reprints availability

- E-prints Service

- Manuscript Podcast for convenient understanding

- Global attainment for your research

- Manuscript accessibility in different formats

(Pdf, E-pub, Full Text, Audio)

- Unceasing customer service

Track the below URL for one-step submission

https://juniperpublishers.com/online-submission.php 